\title{
Mitä teollisuus odottaa aikuis- koulutuksen tutkimukselta
}

\section{MOTTO}

Se joka osaa, tekee.

Joka ei osaa tehdä, kouluttaa.

Joka ei osaa kouluttaa, tutkii koulutusta.

Joka ei pysty tutkimaan koulutusta.

suunnittelee koulutustutkimusohjelmia.

Joka ei kykene tähänkään, pohtii

koulutustutkimusideologioita.

Jolla ei ole lahjoja, näihin pohdiskeluihin, se laatii mietelauseita koulutus-

tutkimusideologioista.

Peruskoulutustason kohoamisen ja teknisen kehityksen myötä aikuiskoulutuksen merkitys yhteiskunnan voimavarana tulee entistä tärkeämmäksi. Painopiste on kuitenkin selvästi ammatillisessa aikuiskoulutuksessa. Näin voidaan omalta osaltaan taata suomalaisten korkea ammattitaidon tason saavuttaminen ja säilyttäminen sekä luoda edellytyksiä aineellisen ja henkisen hyvinvointimme parantamiselle.

\section{Aikuiskoulutuksen tavoitteita}

Aikuiskoulutustutkimuksessa tulee ottaa huomioon aikuiskoulutuksen tavoitteet. Teollisuuden kannalta näitä ovat:

1. Koulutuksella tulee pystyä parantamaan kannattavuutta, kilpailukykyä ja tuottavuutta, jolla puolestaan on keskeinen vaikutus työllisyyden paranemiseen.

2. Koulutuksen on autettava ja helpotettava yritysten ja ihmisten joustavaa sopeutumista työvoimatarpeen muutoksiin.

3. Koulutuksen tulee pitää yllä ja edistää ammattitaitoa; tiedot, taidot ja asenteet mukaan lukien.

4. Koulutuksen tulee helpottaa ja tukea yksilöiden itsensä kehittämistä sekä edistää uralla etenemistä henkilön halujen ja kykyjen mukaisesti.

5. Ammatillisella aikuiskoulutuksella on pystyttävä korjaamaan myös niitä puutteita, joita yhteiskunnan tarjoamassa peruskoulutuksessa pakostakin jää pois sen yleisluontoisuuden vuoksi. 


\section{Koulutustarve ratkaisee sisällön ja määrän}

Ammatillisen aikuiskoulutuksen tarjonnan tulee perustua todettuun koulutustarpeeseen. Koulutustarvetta on, kun henkilöltä puuttuu niitä tietoja, taitoja tai asenne, joita nykyisen tai tulevan tehtävän menestyksellinen suorittaminen edellyttää ja puuttuvia valmiuksia voidaan lisätä koulutuksella.

Koulutustarve vaihtelee. Tärkeämpiä ammatillisen aikuiskoulutuksen kohderyhmiä ovat henkilöt tai henkilöstöryhmät, jotka toimivat

1. kansantalouden ja ulkomaankaupan kannalta keskeisillä aloilla

2. nopeasti kehittyvillä ja muuttuvilla aloilla

3. työllisyyttä edistävillä aloilla

\section{Keinot toteuttaa koulutus}

Ammatillista lisäkoulutusta annetaan monissa ammatillisissa oppilaitoksissa, yliopistoissa ja korkeakouluissa, elinkeinoelämässä sekä yksityisten kurssien järjestäjien ja konsulttien toimesta. Tarjontaa on, mutta niin tuntuu olevan koulutustarpeitakin. Näiden tyydyttäminen ei kuitenkaan edellytä uusien oppilaitosten ja aikuiskoulutusinstituutioiden perustamista.

Nykyisten toimintaa voidaan tehostaa. Keinoja ovat:

1. Koulutuskäsitteen laajentuminen, esim. koulutus työssä.

2. Kannustaminen itsensä kehittämiseen - omaehtoisen opiskelun lisääminen.

3. Valmiin kapasiteetin käyttöasteen nostaminen

- ilta- ja viikonloppuopetus

- loma-ajat

4. Didaktinen tehostaminen

- opettajakoulutus, mm. OTO-opettajat

- monimuoto-opetus

- atk-avusteinen opetus

- radion ja TV:n hyväksi käyttö

5. Koulutuksen tuottavuuden nosto

- motivaatio ja asenteet

- oppimistulosten seuranta

- koulutuksen relevanssı

6. Tutkimus ja tuotekehitys

- koulutustarpeen selvittäminen

- tavoitteet käytännöstä

- kansainvälisyyden hyödyntäminen

7. Markkinointi kohderyhmien selvittäminen

- kursseista tiedottaminen

\section{Tutkimusaiheita}

Ammatillisen aikuiskoulutuksen kehittämisen tulisi perustua nykyistä enemmän kokeiluihin ja tutkimukseen. Tämä edellyttää, että tutkimuksen tavoitteet johdetaan käytännön ongelmista. Erityistä huomiota olisi kiinnitettävä myös tut kimustuloksista tiedottamiseen, ts. tulokset olisi käännettävä "'käytännön kielelle". Lisäksi on katsottava tulevaisuuteen eikä tuijotettava menneisyyteen, tulevaisuuden visiot pohjaksi.

Aikuiskoulutukseen kohdistuvaa tutkimusta tehdään maassamme, mutta se ei ole riittävää eikä elinkeinoelämän kannalta oikein kohdennettuakaan. Painopiste on ollut yleissivistävässä aikuiskoulutuksessa, vaikka tarpeet ovat ammatillisessa aikuiskoulutuksessa.

Jatkossa tutkimusta tulisi suunnata esimerkiksi seuraaville aihealueille:

1. Motivaatiotut kimus

Tarvitsemme tutkimuspohjaista tietoa, mitkä tekijät vaikuttavat haluun opiskella ja miten nämä tekijät eroavat eri ammattiryhmissä tai eri koulutusaloilla, -tasoilla ja -muodoissa.

2. Kustannus - hyöty - ja koulutuksen vaikuttavuus -tutkimus

Koulutusta tulisi tarkastella kustannus-hyöty -periaatteen mukaisesti. Aineellisen ja henkisen hyvinvointimme kehittäminen edellyttää jatkuvaa ammattitaidon kehittämistä. Koska resurssit ovat rajalliset, tulisi panokset suhteessa hyötyihin pyrkiä optimoimaan mahdollisimman hyvin.

3. Koulutustarpeen arviointimenetelmien kehittäminen

Ammatillista ja yleissivistävää aikuiskoulutusta järjestetään maassamme runsaasti, mutta tarvearviot perustuvat useimmiten "'MUTU" ja "SOTU" -menetelmiin (musta tuntuu ja sormituntuma). Systemaattista tarpeiden arvioimista käytetään vielä varsin vähän. Väittäisinkin, että syy on käyttökelpoisten ja yksinkertaisten menetelmien puutteesta.

4. Ammatti- ja tehtävärakenteen kehityksen ennakoiminen.

Koulutuksen kehittämistyön tulisi perustua systemaattisen elinkeinoelämän ammattien analysoimiseen, ts. kunkin ammatin sisällöin selvittämiseen, ammatin kuvauksen laatimiseen sekä opetussuunnitelmien muokkaamisen eri tehtävissä vaadittavien lisätietojen, taitojen ja asenteiden mukaisesti.

Kysymys on siitä, miten tuotantoelämä kehittyy ja mitä vaikutuksia sillä on ammatil- 
lisen aikuiskoulutuksen määrään ja sisältöön. Järjestelmällinen ammatti- ja tehtävärakenteiden tutkiminen luo vahvan perustan myös tulevaisuuden ennustamiselle.

5. Aikuiskoulutusta koskevien tutkimusten kokoaminen

Suomessa ja muissa teollisuusmaissa on tehty runsaasti tutkimusta eri ammatillisen aikuiskoulutuksen osa-alueelta. Tämä koskee varsinkin yritysten henkilöstökoulutusta. Jotta jo omeassa oleva tutkimustieto voitaisiin hyödyntää käytännön kehittämisessä, tulisi tiedot kerätä aihealueittain yhteen paikkaan.

6. Uusien opetusmenetelmien kehittäminen

Uusi tekniikka on vapautunut opetuksen ajan ja paikan kahleista. ATK:ta, videoita, yleisradiotoimintaa tai satelliitteja käytetään vielä liian vähän hyväksi aikuiskoulutuksessa. Etäis- ja monimuoto-opetuksen käyttöönottoa ja tehostamista maassamme lienee vaikeuttanut tiedon puute. Tarvittaisiinko tässä aikuiskoulutusta?

7. Yrittäjyyden edistäminen

Suomalaisen yhteiskunnan hyvinvointi perustuu yrittäjyyteen ja yrittäjiin. Yritystoiminnassa on toivomme myös tulevaisuudessa. Missään ei ole kuitenkaan riittävästi vaivauduttu pohtimaan, millä keinoilla sekä sisäistä yrittäjyyttä että yrittäjäksi ryhtymistä voitaisiin koulutuksen avulla parantaa. Ongelmana on, millä koulutuksella, työkokemuksella, persoonallisuuden piirteillä, motiiveilla jne. yrittäjäksi ryhdytään. Mitkä ovat kaikille yrittäjille välttämättömät perusvalmiudet?

\section{Päättötutkinto ja seuranta}

Tarkat tavoitteet, hyvin järjestetty opetus sekä tulosten seuranta jämäköittävät koulutusta. Elinkeinoelämästä löytyy esimerkkejä, joissa seurannalla on parannettu tuottavuutta kymmeniä prosentteja. Seuranta on osoittautunut halvimmaksi keinoksi tehostaa toimintaa. Olisikin korkea aika koota tutkimustietoa ja kehittää uusia tutkimuksia selvittämään, miten päättötutkintojärjestelmä ja tutkinnot ylipäätänsä lisäävät motivaatiota koulutukseen ja tehostavat oppimistuloksia.

Kutakin ongelma-aluetta ja tutkimusta varten tulisi

ottaa tavoitteet käytännöstä

- asettaa oma vastuuhenkilö

- laatia pitävä aikataulu

- varata riittävät resurssit

- päättää seurannasta sekä

- luoda elinkeinoelämän edustajista ja muista asiantuntijoista tukiryhmä.

Työtä koordinoikoon opetusministeriö yhdessä aikuiskoulutusneuvoston ja sen eri jaostojen kanssa. Määrärahat ammatillisen aikuiskoulutuksen kehittämistä varten vaadittaviin tutkimusaiheisiin ja kokeiluihin tulisi varata vuosittain valtion budjettiin.

Tässä yhteydessä tulisi koulutuksen kenttää tarkastella kokonaisuutena ja olla valmis painopistemuutoksiin. Yleissivistävän koulutuksen tut kimukseen - niin tärkeää kuin se onkin - on panostettu vuosia hyvin runsaasti. Nyt tarvittaisiin samanlaista kehitystä ammatillisen aikuiskoulutuksen puolella. Tulevaisuuden ongelma eivät ole nuoret, vaan yli 50-kymppiset. 